\title{
Fecal occult blood: a comparison of chemical and immunochemical tests
}

\author{
Luana Vilarinho BORGES, Rejane MATTAR, Joyce Matie Kinoshita da SILVA, \\ Ana Luiza Werneck da SILVA, Flair José CARRILHO and Cláudio Lyoiti HASHIMOTO
}

Received 16/8/2017 Accepted 18/12/2017

\begin{abstract}
Background - Colorectal bleeding is a warning sign that may be identified by fecal occult blood testing. A positive fecal occult blood test result requires a subsequent colonoscopy, a costly and invasive examination. Therefore, the use of diagnostic tests with optimal sensitivity and specificity is warranted. In this study, we evaluated four different fecal occult blood tests in 176 patients undergoing colonoscopy and compared their results. Objective - To assess the sensitivity, specificity and predictive values of chemical and immunochemical fecal occult blood tests in patients undergoing colonoscopy and to evaluate the degree of concordance between the tests and colonoscopy. Methods - Patients with indications for colonoscopy also underwent fecal occult blood testing by chemical (toluidine test) and immunochemical methods, employing three commercially available kits. Based on the endoscopic findings, the colonoscopy was rated as positive or negative for colorectal bleeding. The degree of concordance between the fecal occult blood tests and the colonoscopy was evaluated by the kappa index. Results - Forty-four (25\%) colonoscopies were categorized as positive for colorectal bleeding. The toluidine test presented lower concordance than the immunochemical tests, which showed moderate concordance with the colonoscopy. The toluidine test had the least sensitivity, specificity, and positive and negative predictive values. Conclusion - The immunochemical fecal occult blood tests showed greater sensitivity, specificity and predictive values in detecting colorectal bleeding. The immunochemical tests had superior indexes of agreement with colonoscopy compared to the toluidine test.
\end{abstract}

HEADINGS - Occult blood. Toluidines. Immunologic tests. Colonoscopy. Sensitivity and specificity. Predictive value of tests.

\section{INTRODUCTION}

Gastrointestinal tract bleeding, whether evident or occult, is potentially a hazardous symptom or sign and should not be ignored. The differential diagnosis includes benign and malignant conditions. Colorectal cancer (CRC) warrants special diagnostic consideration because it is frequently lethal. Screening programs for populations at average risk for CRC have been recommended strongly by the health organizations of various nations ${ }^{(1-3)}$. Although the screening strategies vary among the countries in which they are implemented, they invariably include two options: a fecal occult blood test (FOBT) and lower digestive tract endoscopy (rectosigmoidoscopy and/or colonoscopy) ${ }^{(2,4-6)}$.

FOBTs are widely accepted as non-invasive and highly costeffective methods of CRC screening. Initially, the guaiac test, which employs a reaction with the heme fraction of hemoglobin, was used for the detection of occult bleeding. Despite its well-documented role in the reduction of CRC mortality ${ }^{(7-10)}$, this method has low sensitivity and a high false-positive rate. More recently, immunochemical tests, which are specific for the identification of human hemoglobin, have attracted increased interest due to their greater sensitivity in detecting advanced adenomas and neoplasms ${ }^{(11)}$. More recently, fecal testing combining immunochemical tests and multiple DNA markers associated with CRC was introduced with the goal of increasing the sensitivity of detection not just of CRC but also of advanced adenomas ${ }^{(12)}$.

Colonoscopy is considered the "gold standard" diagnostic test for CRC detection ${ }^{(4)}$; however, it is an invasive procedure that involves risk ${ }^{(13,14)}$, high cost and requires bowel preparation with restricted diets and strong laxatives ${ }^{(15,16)}$. Patients with positive FOBT results must undergo a complementary investigation to identify the etiology of the bleeding. Thus, the FOBT method clearly should be sufficiently accurate to prompt further investigation only for those patients with actual colorectal bleeding.

Many laboratories in Brazil are believed to use the guaiac-based test as the principal tool for fecal occult blood detection. Developing countries may also use this "in-house" technique, also called the ortho toluidine (toluidine) test, in which the reagents are applied to the sample in the laboratory.

The purpose of this study was to evaluate the sensitivity, specificity, positive predictive value and negative predictive value of different types of FOBT, including chemical and immunochemical methods, in ambulatory patients undergoing colonoscopy. In the present study, three immunochemical tests and the ortho toluidine test were used in 176 patients who subsequently underwent colonoscopy, and the results were prospectively compared. 


\section{METHODS}

\section{Subjects}

This study was approved by the local Ethics Committee. The inclusion criteria were patients older than 14 years of both genders who had indications for colonoscopy and who attended at the Clinics Hospital of the University of São Paulo Medical School, São Paulo, Brazil. The exclusion criteria were the patients who reported hematochezia or hematuria in the preceding seven days, women who were menstruating and patients who refused to follow a restricted diet (free of tomatoes, radishes, beets, deeply colored liquids and red meat) in the two days preceding the exam. All patients included in the study gave written informed consent and underwent both colonoscopy and FOBT.

\section{FOBT}

Feces were collected the day before the colonoscopy. The patients were instructed to evacuate in a dry, clean environment, store the feces sample in a universal collection flask and maintain the sample under refrigeration until delivered. All samples were analyzed using the toluidine test and three commercially available immunochemical tests: BioNexia ${ }^{\circledR} \mathrm{Hb} / \mathrm{Hp}$ Complex (Dima Diagnostika, Germany), Imuno Rápido Sangue Oculto ${ }^{\circledR}$ (Wama Diagnóstica, Brazil) and Feca-Cult One Step Teste ${ }^{\circledR}$ (Alamar Tecno Científica LTDA, Brazil).

All FOBTs were performed by the same investigator, who was blind to the colonoscopy results. The FOBT results were considered positive or negative. Hydrogen peroxide and toluidine were used for the "in-house" FOBT technique. The reaction was considered positive when the initially colorless product developed a dark greenish-blue color and negative when no color change occurred after two minutes (FIGURE 1). The interpretation of the BioNexia ${ }^{\circledR} \mathrm{Hb} / \mathrm{Hp}$ Complex, Imuno Rápido Sangue Oculto ${ }^{\circledR}$ and Feca-Cult One Step Teste ${ }^{\circledR}$ results were based on the appearance of colored bands provided in the test kit, according to the manufacturer recommendations, with detection of human hemoglobin at concentrations of $25 \mathrm{ng} / \mathrm{mL}, 50 \mathrm{ng} / \mathrm{mL}$ and $40 \mathrm{ng} / \mathrm{mL}$, respectively (FIGURES 2, 3 and 4).

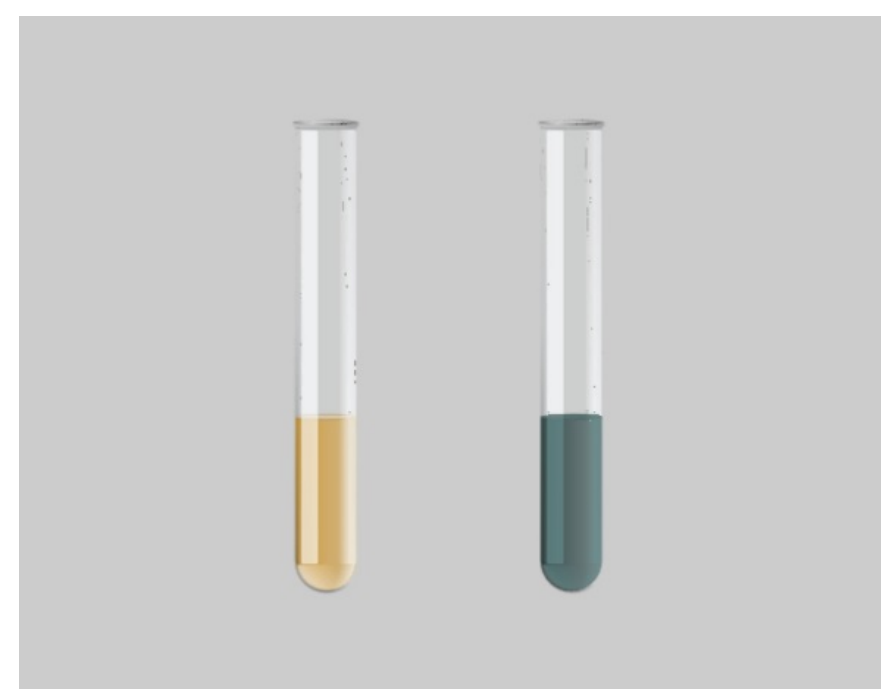

FIGURE 1. Visual interpretation of the toluidine test. Yellowish color indicates negative test and blue-green color indicates positive test.

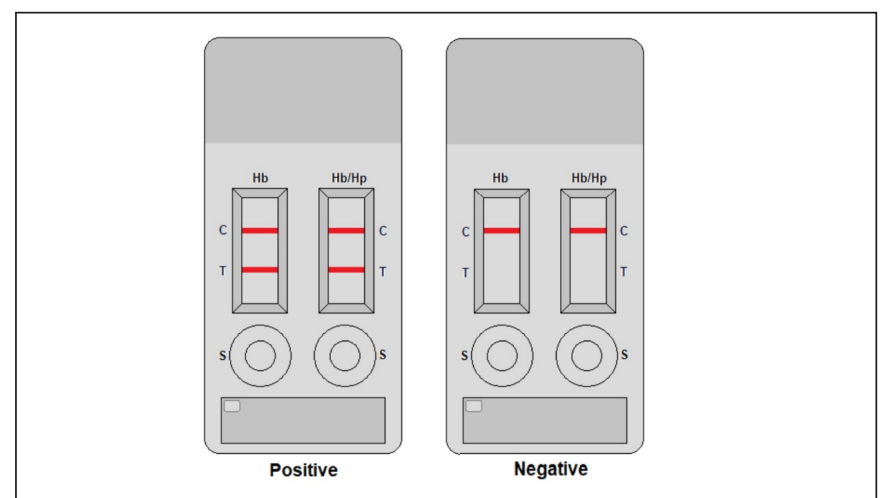

FIGURE 2. Visual interpretation of the BioNexia ${ }^{\circledR} \mathrm{Hb} / \mathrm{Hp}$ Complex test. The appearance of two lines indicates positive test and the appearance of one line indicates negative test.

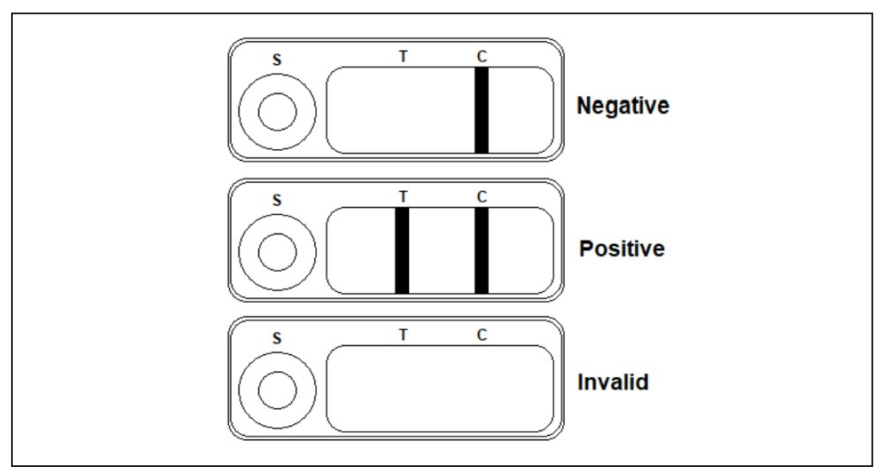

FIGURE 3. Visual interpretation of the Imuno Rápido Sangue Oculto ${ }^{\circledR}$ test. The appearance of one line indicates negative test and the appearance of two lines indicates positive test. Non-line appearance indicates invalid test.

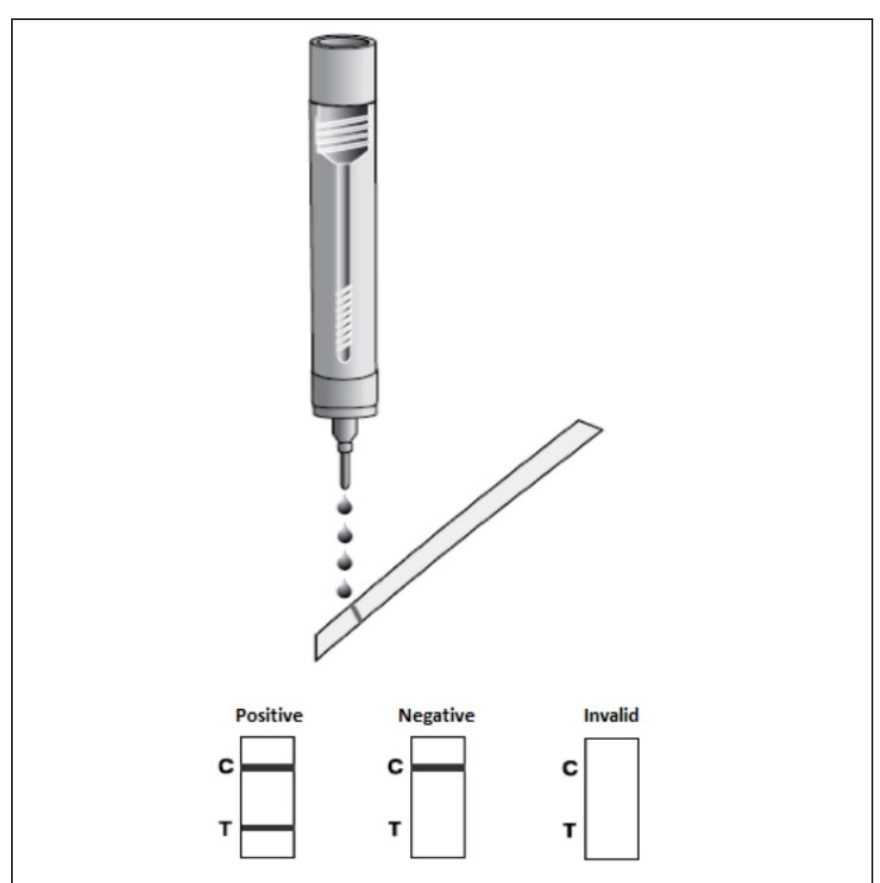

FIGURE 4. Visual interpretation of the Feca-Cult One Step Teste ${ }^{\circledR}$ test. The appearance of two lines indicates positive test and the appearance of a line indicates negative test. Non-line appearance indicates invalid test. 


\section{Colonoscopy}

Following bowel preparation, the colonoscopies were performed under conscious sedation by experienced endoscopists blind to the FOBT results. The colonoscopy results were categorized as positive or negative according to the respective presence or absence of a colorectal bleeding source.

Colonoscopy was considered positive when the findings were consistent with colorectal bleeding, that is, active inflammatory bowel disease, diverticular disease with bleeding, vascular lesions with signs of bleeding, active mucosal inflammation, polyps $\geq 10$ $\mathrm{mm}$, and early or advanced neoplasia. Colonoscopy was considered negative when the cecum was reached under conditions of adequate bowel preparation and no conditions associated with colorectal bleeding were detected.

\section{Statistical analysis}

Statistical analysis of the diagnostic tests was performed using the kappa measure-of-agreement index and PASW Statistics 18. A $P$ value of $<0.05$ was considered statistically significant.

\section{RESULTS}

The study included 114 women $(64.8 \%)$ and 62 men (35.2\%) with a mean age of 55.5 years. Forty-five $(25 \%)$ colonoscopies were categorized as positive and $132(75 \%)$ were negative according to the criteria regarding the colorectal bleeding source. The correlation between the FOBTs and colonoscopy and their respective kappa values are shown in TABLE 1 .

Agreement between each FOBT test and the colonoscopy was evaluated using the kappa statistic. The toluidine test showed slight agreement (kappa 0.00-0.19), whereas the immunochemical tests demonstrated moderate agreement (kappa 0.40-0.59).

The sensitivity, specificity, positive predictive value and negative predictive value for each FOBT test were evaluated separately for colonoscopies, considering positive or negative for a possible source of colorectal bleeding (TABLE 2).

Seventy-two $(40.9 \%)$ patients had consumed at least one foodstuff that might result in a false-positive toluidine test (TABLE 3). According to the kappa index, the agreement between

TABLE 1. Results of FOBTs and colonoscopy categorization.

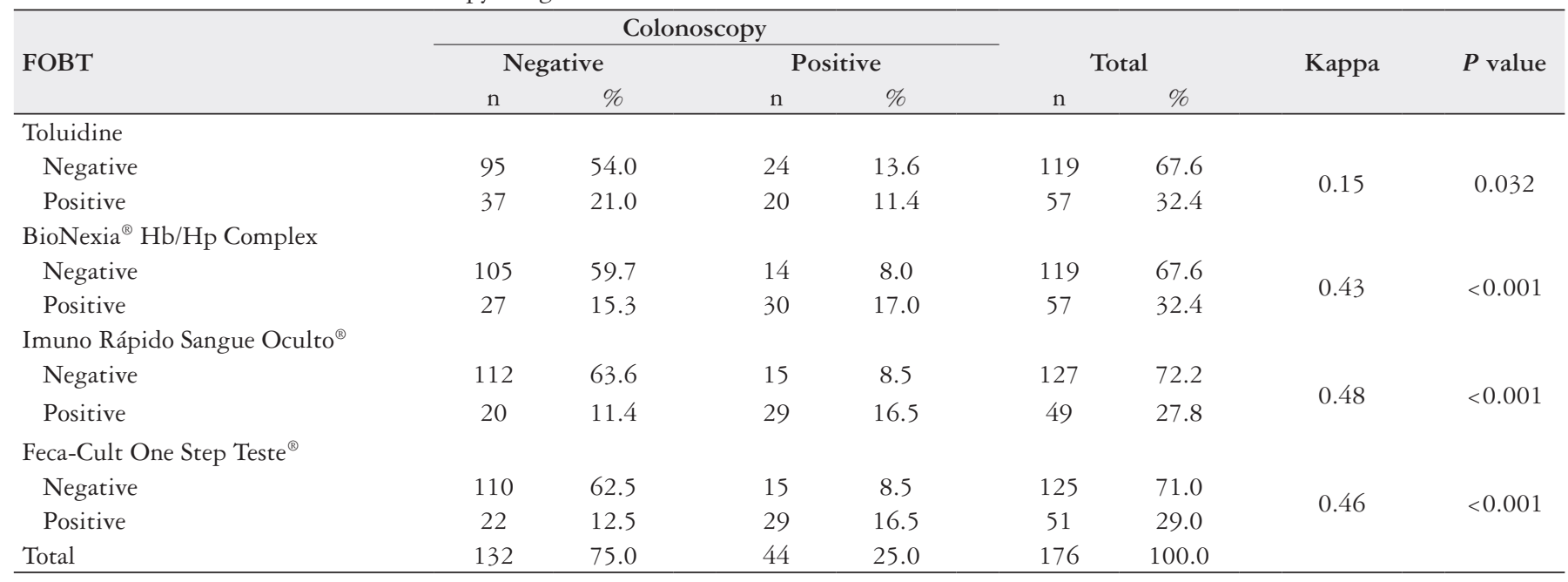

FOBT: fecal occult blood test.

TABLE 2. Sensitivity, specificity, positive predictive value and negative predictive value of the FOBTs.

\begin{tabular}{lcccc}
\hline \multirow{2}{*}{ Measure } & \multicolumn{4}{c}{ FOBT } \\
\cline { 2 - 5 } & Toluidine & BioNexia $^{\circledR}$ Hb/Hp Complex & Imuno Rápido Sangue Oculto $^{\circledR}$ & Feca-Cult One Step Teste $^{\circledR}$ \\
\hline Sensitivity & $45.5 \%$ & $68.2 \%$ & $65.9 \%$ & $65.9 \%$ \\
Specificity & $72 \%$ & $79.5 \%$ & $84.8 \%$ & $83.3 \%$ \\
PPV & $35.1 \%$ & $52.6 \%$ & $59.2 \%$ & $56.9 \%$ \\
NPV & $79.8 \%$ & $88.2 \%$ & $88.2 \%$ & $88 \%$ \\
\hline
\end{tabular}

FOBT: fecal occult blood test; PPV: positive predictive value; NPV: negative predictive value.

TABLE 3. Toluidine FOBT results in relation to colonoscopy in the group that did not follow the recommended diet.

\begin{tabular}{|c|c|c|c|c|c|c|}
\hline \multirow{3}{*}{ FOBT } & \multicolumn{4}{|c|}{ Colonoscopy } & \multirow{2}{*}{\multicolumn{2}{|c|}{ Total }} \\
\hline & \multicolumn{2}{|c|}{ Negative } & \multicolumn{2}{|c|}{ Positive } & & \\
\hline & $\mathrm{n}$ & $\%$ & $\mathrm{n}$ & $\%$ & $\mathrm{n}$ & $\%$ \\
\hline \multicolumn{7}{|l|}{ Toluidine } \\
\hline Positive & 13 & 18.1 & 12 & 16.7 & 25 & 34.7 \\
\hline Total & 49 & 68.1 & 23 & 31.9 & 72 & 100 \\
\hline
\end{tabular}

FOBT: fecal occult blood test. 
the test evaluated and the colonoscopy was considered weak $(P=0.03$; kappa $=0.25)$.

In total, ten patients $(5.7 \%)$ used antiplatelet drugs, oral anticoagulants or nonsteroidal anti-inflammatory drugs. The interference of these medicines was analyzed with respect to the results of the four FOBTs, as shown in TABLE 4.

TABLE 4. Evaluation of the FOBTs in relation to colonoscopy in the group that used interfering medications.

\begin{tabular}{|c|c|c|c|c|c|c|}
\hline \multirow{3}{*}{ FOBT } & \multicolumn{4}{|c|}{ FOBT Results } & \multirow{3}{*}{ Kappa } & \multirow{3}{*}{$P$ value } \\
\hline & \multicolumn{2}{|c|}{ True-negative } & \multicolumn{2}{|c|}{ True-positive } & & \\
\hline & $\mathrm{n}$ & $\%$ & $\mathrm{n}$ & $\%$ & & \\
\hline Toluidine & 6 & 60 & 0 & 0 & 0.25 & 0.429 \\
\hline $\begin{array}{l}\text { BioNexia }{ }^{\circledR} \mathrm{Hb} / \\
\text { Hp Complex }\end{array}$ & 5 & 50 & 1 & 10 & 0.09 & 0.747 \\
\hline $\begin{array}{l}\text { Imuno Rápido } \\
\text { Sangue Oculto }\end{array}$ & 6 & 60 & 1 & 10 & 0.21 & 0.49 \\
\hline $\begin{array}{l}\text { Feca-Cult One } \\
\text { Step Teste }^{\circledR}\end{array}$ & 6 & 60 & 1 & 10 & 0.21 & 0.49 \\
\hline
\end{tabular}

FOBT: fecal occult blood test.

No agreement was observed $(P>0.05)$ between the FOBT and colonoscopy results in those patients who used at least one interfering medication.

\section{DISCUSSION}

A recent meta-analysis ${ }^{(16)}$ compared chemical to immunochemical FOBTs. That study included five randomized clinical trials that enrolled more than 20,000 patients and 11 cohort studies. Compared with these systematically reviewed data, the toluidine test in our study showed less sensitivity (45\% versus $54 \%$ ) and less specificity $(72 \%$ versus $80 \%)$ than the guaiac-based tests. In contrast, the commercially available immunochemical tests in the current study showed sensitivity and specificity similar to that described by Zhu et al. in the meta-analysis ${ }^{(17)}$. One multicenter study on nearly 10000 patients comparing fecal DNA test $\left(\right.$ Cologuard ${ }^{\circledR}$ ) to immunochemical test using colonoscopy as the gold standard showed that the fecal DNA test had a higher sensitivity detecting CRC (92\% vs. 74\%). Fecal DNA test had lower specificity at $87 \%$ $90 \%$ compared to immunochemical test $(95 \%-96 \%)^{(12)}$.

Since $1971^{(18)}$, dietary restrictions have been recommended on the days preceding the collection of fecal samples for analysis by guaiac-based tests ${ }^{(10)}$. However, a systematic review ${ }^{(19)}$ reported that no evidence existed to justify the recommendation of dietary restriction prior to the collection of feces for guaiacbased method. Regarding the toluidine test in the present study, the ingestion of peroxidase-rich foodstuffs was associated with better agreement between the colonoscopy and the fecal test among those patients who did not follow the dietary restriction instructions compared to those who did. It is possible that the quantity ingested may have been insufficient to alter the FOBT result. Vitamin $\mathrm{C}$, present in the fruit juices used for hydration during the bowel preparation, probably inhibited the enzymatic action and interfered with the results. We believe that detailed information on the daily diet and considering the quantity and quality of the food might clarify these hypotheses.

In patients using medications with anticoagulant properties, no agreement was observed between the FOBT and colonoscopy results, similar to the observations of Clarke et al. ${ }^{(20)}$. In the present study, these medicines possibly altered the results of the fecal tests. This hypothesis requires careful analysis, considering the small number of study patients using antiplatelet, oral anticoagulant or nonsteroidal anti-inflammatory drugs.

FOBT effectiveness is well known to depend on the collection and storage of the feces, the frequency of the bleeding, the type of test employed and the interpretation of the results. In this study, the fecal collection method was unlikely to have interfered with the results, thereby confounding the results of some of the FOBTs, because all the analyses were performed using the same fecal sample and the samples that were not adequately stored were disregarded. Understandably, any lesion identified as a potential source of hemorrhage may bleed intermittently. Despite the collection of samples within the shortest interval possible in relation to the colonoscopy, actively bleeding foci were not ensured at the sample collection time. Notably, whereas the immunochemical tests have well defined detection limits, the minimal hemoglobin concentration detectable by the toluidine test is not known. The interpretation of the toluidine test results may be affected by many factors, such as the reagent preparation, dilution of the feces, and skill of the operator reading the results, including the interpretation of the color obtained. One study showed that considerable variations in interpretation occurred with the use of a chemical FOBT ${ }^{(21)}$.

Anal diseases might have influenced the results of the fecal tests. Primarily, hemorrhoidal bleeding may be a cause of false-positive FOBT results ${ }^{(22)}$. We conducted a pilot study involving proctologic examinations to evaluate those patients with false-positive FOBT results. However, difficulties in defining the possible sources of orificial bleeding discouraged us from proceeding with this complementary evaluation.

The main limitation of the present study was defining positive and negative results of the colonoscopy, which is considered the "gold standard" method for colorectal disease detection. The categorization of the colonoscopy results regarding the likely source of colorectal bleeding is fundamental for the veracity of this study. Moreover, most publications on FOBT are studies of population screening, with large sample sizes for the diagnosis of invasive CRC and advanced adenomas. The current recommendations for CRC screening by FOBT are the evaluation of three samples for guaiacbased tests and one or two samples for the immunochemical tests ${ }^{(4,22)}$.

\section{CONCLUSION}

Immunochemical FOBTs were superior in sensitivity, specificity, positive predictive value and negative predictive value compared to the toluidine chemical test in evaluating the source of colorectal bleeding by the analysis of one fecal sample.

The three immunochemical tests used in this study had an acceptable degree of concordance with the colonoscopy and similar performance to each other.

Finally, this study examined the practicality of using immunochemical tests in public hospitals in developing countries, where the likelihood of adequate refrigerated fecal conservation and the viability of the samples following transport to the hospital are often unknown. 


\section{ACKNOWLEDGMENTS}

To Dr José Guilherme Nogueira da Silva and Dra Adriana Vaz Safatle-Ribeiro for contribution in text review. To Alka Tecnologia em Diagnósticos, Wama Diagnóstica and Interlab by donation of kits used in the study.

\section{Authors' contribution}

Borges LV: data collection, writing of text, review. Mattar R: statistical analysis, survey execution, review. Silva JMK: data collection. Silva ALW: writing of text. Carrilho FJ: review. Hashimoto CL: data collection, survey execution, review.

Borges LV, Mattar R, Silva JMK, Silva ALW, Carrilho FJ, Hashimoto CL. Sangue oculto nas fezes: uma comparação entre os métodos químico e imunoquímico. Arq Gastroenterol. 2018;55(2):128-32.

RESUMO - Contexto - O sangramento colorretal é considerado um sinal de alarme e não deve ser ignorado. O resultado positivo de um teste de pesquisa de sangue oculto nas fezes (PSOF) requer investigação complementar com colonoscopia, exame invasivo e de alto custo. Justifica-se, portanto, a aplicação de um teste diagnóstico mais sensível e específico. No presente estudo, foram avaliados quatro diferentes testes de PSOF em 176 pacientes submetidos à colonoscopia e seus resultados foram comparados. Objetivo - Avaliar a sensibilidade, a especificidade e os valores de predição dos testes químico e imunoquímico de PSOF em pacientes submetidos à colonoscopia e avaliar o grau de concordância entre os testes de PSOF e a colonoscopia. Métodos - Pacientes com indicação de realizar colonoscopia foram submetidos também à PSOF pelo método químico (o-toluidina) e pelo método imunoquímico, empregando três kits comerciais disponíveis no mercado. Fundamentado nos achados endoscópicos, a colonoscopia foi categorizada em positiva ou negativa, de acordo com a possível fonte de sangramento colorretal. O grau de concordância entre os testes de PSOF foi avaliado pelo índice kappa. Resultados - Quarenta e quatro (25\%) colonoscopias foram categorizadas como positivas quanto à fonte de sangramento colorretal. O teste da $o$-toluidina mostrou menor concordância que os testes imunoquímicos, os quais apresentaram moderada concordância com a colonoscopia. $\mathrm{O}$ teste da $o$-toluidina revelou menor sensibilidade, especificidade, valor preditivo positivo e valor preditivo negativo. Conclusão-Os testes imunoquímicos revelaram maior sensibilidade, especificidade e valores de predição na detecção de sangramento colorretal. Os testes imunoquímicos apresentaram melhores índices de concordância com a colonoscopia, quando comparados ao teste da $o$-toluidina.

Descritores - Sangue oculto. Toluidinas. Testes imunológicos. Colonoscopia. Sensibilidade e especificidade. Valor preditivo dos testes.

\section{REFERENCES}

1. Rhodes JM. Colorectal cancer screening in the UK: Joint Position Statement by the British Society of Gastroenterology, The Royal College of Physicians, and The Association of Coloproctology of Great Britain and Ireland. Gut. 2000;46:746-8.

2. Winawer S, Fletcher R, Rex D, Bond J, Burt R, Ferrucci J, et al. Colorectal cancer screening and surveillance: clinical guidelines and rationale-Update based on new evidence. Gastroenterology. 2003;124:544-60.

3. Smith RA, Cokkinides V, Eyre HJ. American Cancer Society guidelines for the early detection of cancer, 2006. CA Cancer J Clin. 2006:56:11-25; quiz 49-50.

4. Levin B, Lieberman DA, McFarland B, Andrews KS, Brooks D, Bond J, et al. Screening and surveillance for the early detection of colorectal cancer and adenomatous polyps, 2008: a joint guideline from the American Cancer Society, the US Multi-Society Task Force on Colorectal Cancer, and the American College of Radiology. Gastroenterology. 2008;134:1570-95.

5. Leddin DJ, Enns R, Hilsden R, Plourde V, Rabeneck L, Sadowski DC, et al. Canadian Association of Gastroenterology position statement on screening individuals at average risk for developing colorectal cancer: 2010. Can J Gastroenterol. 2010;24:705-14

6. Whitlock EP, Lin JS, Liles E, Beil TL, Fu R. Screening for colorectal cancer: a targeted, updated systematic review for the U.S. Preventive Services Task Force. Ann Intern Med. 2008;149:638-58.

7. Mandel JS, Bond JH, Church TR, Snover DC, Bradley GM, Schuman LM, et al. Reducing mortality from colorectal cancer by screening for fecal occult blood. Minnesota Colon Cancer Control Study. N Engl J Med. 1993;328:1365-71.

8. Hardcastle JD, Chamberlain JO, Robinson MH, Moss SM, Amar SS, Balfour TW, et al. Randomised controlled trial of faecal-occult-blood screening for colorectal cancer. Lancet. 1996;348:1472-7.

9. Mandel JS, Church TR, Ederer F, Bond JH. Colorectal cancer mortality: effectiveness of biennial screening for fecal occult blood. J Natl Cancer Inst. 1999;91:434-7.

10. Kronborg O, Fenger C, Olsen J, Jørgensen OD, Søndergaard O. Randomised study of screening for colorectal cancer with faecal-occult-blood test. Lancet. 1996;348:1467-71.
11. van Dam L, Kuipers EJ, van Leerdam ME. Performance improvements of stoolbased screening tests. Best Pract Res Clin Gastroenterol. 2010;24:479-92.

12. Issa IA, Noureddine M. Colorectal cancer screening: An updated review of the available options. World J Gastroenterol. 2017;23:5086-96.

13. Rabeneck L, Paszat LFvv, Hilsden RJ, Saskin R, Leddin D, Grunfeld E, et al. Bleeding and perforation after outpatient colonoscopy and their risk factors in usual clinical practice. Gastroenterology. 2008;135:1899-906, 906.e1.

14. Warren JL, Klabunde CN, Mariotto AB, Meekins A, Topor M, Brown ML, et al. Adverse events after outpatient colonoscopy in the Medicare population. Ann Intern Med. 2009;150:849-57,W152.

15. Davis GR, Santa Ana CA, Morawski SG, Fordtran JS. Development of a lavage solution associated with minimal water and electrolyte absorption or secretion. Gastroenterology. 1980;78(5 Pt 1):991-5.

16. Froehlich F, Wietlisbach V, Gonvers JJ, Burnand B, Vader JP. Impact of colonic cleansing on quality and diagnostic yield of colonoscopy: the European Panel of Appropriateness of Gastrointestinal Endoscopy European multicenter study. Gastrointest Endosc. 2005;61:378-84.

17. Zhu MM, Xu XT, Nie F, Tong JL, Xiao SD, Ran ZH. Comparison of immunochemical and guaiac-based fecal occult blood test in screening and surveillance for advanced colorectal neoplasms: a meta-analysis. J Dig Dis. 2010;11:148-60.

18. Greegor DH. Occult blood testing for detection of asymptomatic colon cancer. Cancer. 1971;28:131-4

19. Konrad G. Dietary interventions for fecal occult blood test screening: systematic review of the literature. Can Fam Physician. 2010;56:229-38.

20. Clarke P, Jack F, Carey FA, Steele RJ. Medications with anticoagulant properties increase the likelihood of a negative colonoscopy in faecal occult blood test population screening. Colorectal Dis. 2006;8:389-92.

21. Selinger RR, Norman S, Dominitz JA. Failure of health care professionals to interpret fecal occult blood tests accurately. Am J Med. 2003;114:64-7.

22. Ouyang DL, Chen JJ, Getzenberg RH, Schoen RE. Noninvasive testing for colorectal cancer: a review. Am J Gastroenterol. 2005;100:1393-403. 